\title{
Gilded Creatures Straining and Dying: Performances of Blondness and Feminine Ethereality in Emily Dickinson's Poetry
}

\begin{abstract}
$\mathrm{E}$ mily Dickinson's withdrawal from public and social life could be interpreted as a scrupulous adherence to nineteenth-century conventions of feminine domesticity, but critics now tend to agree that she unsettled traditional gender conventions. The extent and orientation of her subversion remain open to debate. Dickinson's inveterate white attire and circumscribed life of domesticity served as explicit markers of femininity, but in retrospect they form a somewhat ironic persona when set against the dynamic fluidity of gender in her poetry. ${ }^{1}$ On the other hand, her veneer of conventionality also worked against representations of women as performers in nineteenth-century popular culture. Examining Dickinson's engagement with American popular culture has emerged as a strategy in itself for revising the assumption that she rejected her surrounding society in favour of poetic seclusion. Her contact with commercial entertainment may have been limited, but Dickinson did pay attention to trends in theatrical and musical performance. She read contemporary magazines, newspapers, and periodicals, most notably The Springfield Republican, which provided her with information about regional events, cultural happenings, and any
\end{abstract}

1 For example, Peter Stoneley argues that Dickinson took "conventions of proper womanhood—selfeffacing modesty, purity of body and spirit - to such an extreme that their significance was reversed" (579). See also Juhasz and Mossberg for discussions of how Dickinson exaggerated the roles of feminine seclusion and self-effacement. 
mishaps or disasters in the New England area. ${ }^{2}$ Barton Levi St. Armand argues that Dickinson followed contemporary news and popular culture by keeping a scrapbook of "clippings from national magazines, local newspapers, and illustrated books" (26). ${ }^{3}$ Also, George Boziwick notes that Dickinson kept a music book during her adolescence, a collection that attests to her knowledge of and interest in the "musical repertoire of her day," including the various "star performers" (87) who visited America from Europe. The most famous of these "stars" was Jenny Lind, a singer from Stockholm who carried the nickname the "Swedish Nightingale." Featured in the Republican in July of 1851, Lind was the only female celebrity Dickinson saw in live performance. Dickinson might have assembled a hyperbolically feminine persona for her own (and her family's) benefit, but she also seems to have crafted it in partial response to female personages like Lindthat is, woman performers who gained some celebrity, if not notoriety, in mid-to-late nineteenth century American culture.

As critics have discussed, Dickinson's poetry engages not only with feminine performance but also with subjects related to the performativity of gender. Among contemporary scholars, Suzanne Juhasz and Cristanne Miller have established a foundation for reading Dickinson in relation to Judith Butler's theorizations of gender. ${ }^{4}$ Other recent critics like Kathryn Wichelns (79), Cecily Parks, Enikő Bollobás, and Victoria Morgan (201) have considered how Dickinson performs gender through poetry, unbundling traditional conventions and sexist hierarchies in the process. However, in the past few years, others have

2 In an 1853 letter to Elizabeth Holland, Dickinson memorably remarks, "I read in it [the Republican] every night. Who writes those funny accidents, where railroads meet each other unexpectedly, and gentlemen in factories get their heads cut off quite informally?" (L133).

3 This scrapbook has since been lost. To gain an impression of its contents, St. Armand draws upon a surviving scrapbook kept by one of Dickinson's closest friends, Mary Warner. Warner's book, which begins in 1851, consists of clippings from a wide array of newspapers and publications, including Atlantic Monthly, Putnam's Magazine, and Godey's Lady's Book. St. Armand identifies the book as a "theme seeker's talisman, a guiding anthology of ideas, models, and patterns that furnishes us with the prototypes, stereotypes, and archetypes of Dickinson's time" (31). For further discussions of Dickinson's engagement with texts from popular culture, see Cristanne Miller, David Reynolds, and Cheryl Walker.

4 For Juhasz and Miller, her poetry functions as a "liminal space where various aspects of performance and identity collide" (109). Although Dickinson is "rarely overt and frequently not literal about gender," her poetry is "replete with conventional performative signs for indicating that gender is present" (113). At the same time, for a woman in nineteenth-century America, the very act of writing poetry constituted a "gender-bending" performance (125). 
critiqued these developments in Dickinson scholarship. For instance, Ursula Caci argues that Dickinson's poetry is less invested in deconstructing gender than it is in playing with the multiplicity of gender in order to expose the "necessary presence of power in [all $]$ hierarchies" (69). Also, Jessica Jessee argues that the biographical emphasis on the "performance of the poems or poet" has directed attention away from Dickinson's complex portrayals of performance in poetry. Jessee asserts, "Representations of performance in Dickinson's poetry can help us to better appreciate her engagement (however unconventional) with a highly performative mid-century public culture" (1). In this latter approach, readings of performance in Dickinson's poetry raise questions of how she creates scenes in which female (or feminine) figures display complex and often conflicted aspects of mid nineteenth-century theatrical performances involving women.

This article focuses on the ways Dickinson's poetic engagement with mid nineteenth-century feminine theatrical performance (exemplified in particular by Jenny Lind) evolves in relation to a single colour. The colour blonde appears in two poems Dickinson wrote in 1863, "The Moon was but a Chin of Gold" and "You've seen Balloons set - Hav'nt [sic] You?" In these poems, the colour blonde carries analogous meanings while also, I argue, touching upon a major transformation in fashion and culture that occurred in America during the 1850 s and 60s. At once superficial and yet profoundly revealing, this transition was reflected in American literature and theatrical performances. At the midpoint of the nineteenth century, a rapid change occurred in the representation of blonde hair. Dickinson's depictions of blondness suggest that she was attuned to this transition, which centred on tensions between older associations of blonde hair like purity, ethereality, and angelic innocence, and concepts that had previously been allied with dark hair, such as voluptuousness, sensuality, and embodiment. Halfway through the nineteenth century, a productive conflict between these associations, expressed previously mainly through literature, began to emerge in theatrical performances, with blonde-haired female singers and dancers capitalizing on the

5 Dickinson also mentions the word "blonde" in a handful of other poems, including "Dropped into the Ether Acre," "Banish Air from Air," "Apparently with no surprise," and "Color - Caste Denomination -." 
edgy contrast between purity and eroticism to strengthen the piquant appeal of their shows. Dickinson's engagement with and use of the term "blonde" reflect facets of these contrasts, even though she generally does not use the word to refer to hair colour. For instance, Daneen Wardrop ties the use of "blonde" in "Banish Air from Air -" to fabrics and clothing, arguing that in nineteenth-century fashion magazines "blonde" was "probably used more readily as an adjective for lace than it was for hair" (Labor 184). However, Dickinson's poetry does capture shifting connotations of blondness as a marker of identity through select portrayals of the reciprocal movements between clothing, physical appearance, and cultural associations. The colour itself emerges in her poetry as a polysemic and changeable trope for feminine performances that unfold through competing tensions of ethereality and physicality.

Discussing a single colour in relation to Dickinson's poetry inevitably calls to mind the roles of whiteness in her work and life. Dickinson's ambivalent and far-ranging representations of whiteness form a useful point of comparison for thinking about blondness. As critics like Wesley King (44), Vivian Pollak (85), Judith Pascoe (9), and Sandra Gilbert and Susan Gubar have noted, whiteness takes on multiple meanings in Dickinson's poetry, signifying alternatively ethereality, purity, self-sacrifice, racial hierarchies, death, blankness, universality, and other subjects. Moreover, even when whiteness is tied to particular symbolic associations, its meaning often evolves through unstable tensions and paradoxes. For instance, Pollak argues that Dickinson invokes traditional links between whiteness and "feminine self-denial and self-sacrifice" primarily in order to associate herself with a contrary "transgressive and androgynous public style" (89). In a related vein, Gilbert and Gubar argue that whiteness functions for Dickinson as a symbol of purity and a talisman for male fantasies of defilement while also operating simultaneously as a tropological "self-enclosing armor" that buttresses women's autonomy and independence (616-17). Viewed collectively, these critical observations suggest that Dickinson's poetry approaches whiteness not as a totalizing sign that produces repetitious meanings but as a variable marker of competing and even contradictory associations. 
These persistent tensions and ambiguities in Dickinson's poetic treatment of whiteness take on a new dimension when we consider some of the alliances between whiteness and blondness in mid nineteenth-century American culture. There are various ways to approach such alliances, but focusing on the Jenny Lind phenomenon draws attention to one of the paramount ideals at the core of them, feminine purity, ethereality, and innocence. ${ }^{6}$ As numerous critics and historians have discussed, blondness carries longstanding feminized connotations of purity, angelic innocence, ethereality, and youth. ${ }^{7}$ Some critics have gestured towards a link between Dickinson's constructions of whiteness and these associations of blondness, albeit in passing. For example, Gilbert and Gubar discuss Dickinson's engagement with the most famous icon of whiteness in Victorian society, the "angel in the house," a persona that has traditionally been a paragon of visual whiteness on several levels_ not only does she typically wear white clothing, but she is also usually depicted as having pink cheeks and "celestially golden hair, as if to relate her further to the whiteness of heaven" (616). Domhnall Mitchell and Judith Pascoe bring a different angle to this connection through their discussions of Dickinson's attendance at the Jenny Lind concert. Mitchell argues that part of the reason Dickinson attended the concert is that Lind personified an aggregate of symbolizations grounded on notions of purity and virtue, which revolved around light-coloured clothing, racialized whiteness, and a Northern European heritage - a "social as well as aesthetic alignment" (78) in the mid nineteenth-century that appealed to a certain class of Americans (especially those who feared rising levels of immigration from areas outside of Northern Europe). Pascoe also raises these ideas, stating that Lind's popularity was based partly on her reputation for feminine purity and virtue, a stature that was coded through her clothing and appearance, which enabled her to embody "whiteness beyond reproach" (9). Indeed, no doubt part of

6 Lind truly was a phenomenon, arriving in America in 1850 amid extensive media coverage and mass enthusiasm. As Pascoe discusses, it would be difficult to overestimate the scope and reach of her popularity in America: "To attempt to envision the frenzy created by Lind's tour of America, it may be necessary to imagine a contemporary Beatles tour with John Lennon restored to life" (2). Pascoe proceeds to argue that "Jenny Lind, as the most public of public women, served for Dickinson as both an intriguing and troubling example of the female artist in the marketplace," producing a "complex and enduring impact on her conception of herself as an artist" (2).

7 See for example Gelbart (209), Wendy Cooper, Pitman, Joncus (559), and Gitter. 
the reason Dickinson's severe father allowed his daughters to attend the show was that Lind had a widespread reputation for charity and impeachable conduct. ${ }^{8}$

Neither Mitchell nor Pascoe mention Lind's hair colour specifically, and Dickinson does not bring it up in a letter to her brother Austin on July 6, 1851 in which she discusses the Lind concert (though she does comment on Lind's "mild blue eyes" [L46]). There is no concrete proof that Lind was blonde, with surviving daguerreotypes suggesting that her hair was probably light brown (and almost certainly not yellow). Yet interestingly, contemporary depictions of and dialogues about Lind identify her as a strikingly blonde-haired performer, suggesting, I would argue, a series of attempts to bolster her reputation for impeachable "whiteness." In 1866, the American singer Lillie de Hegermann-Lindencrone described her as having "plain features, a pert nose, sallow skin, and very yellow hair." Similarly, John Addington Symonds's rather physiognomic catalogue of her appearance in 1862 included the detail "Her hair is profuse and yellow." Frederick Locker-Lampson, an English poet and famous book collector, described her as a "fair-haired and blue-eyed Puritan" (qtd. in Wagenknecht 24). Either these individuals took creative liberties in their descriptions or Lind dyed her hair at different points in her career. Either way, Locker-Lampson's phrase "fair-haired and blueeyed Puritan" is significant, indicating that the public was invested in galvanizing a link between blondness and innocence to reinforce Lind's persona. The image-production of Lind as a blonde was also a commercialized (and haphazard) process. Many products carried her likeness, from cigars to teakettles to paper dolls, with some items and advertisements depicting her as a brunette, others showing her with

8 Dickinson's droll descriptions of her father's reactions to the show afford a glimpse of how a conservative New Englander might view the intrinsic imprudence of a popular woman entertainer. Dickinson describes her father "looking mad, and silly, and yet so much amused" throughout the performance. When it ended, Edward Dickinson thanked the performers with jarring abruptness and formality, commenting, "Good evening Sir" and "very well-that will do" before they even had a chance to receive applause: "it was'nt sarcasm exactly, nor it was'nt disdain, it was infinitely funnier than either of those virtues, as if old Abraham had come to see the show, and thought it was all very well, but a little excess of Monkey!" (L46). In this instance, the disreputable element to the show is more benign than eroticism, centring on playfulness and silliness. Then again, Edward Dickinson's obvious desire to leave quickly suggests that he was worried the "monkey business" might slide into something worse and more corrupting if he did not whisk his daughters away immediately. 
somewhat lighter shades of hair, and still others, such as the paper dolls, representing her with yellow blonde locks.' Given the importance of whiteness as a symbol for Lind's ostensible angelic purity and beneficence, it is possible that representations of her as a blonde were aimed in part at strengthening her overall public image.

At the same time, the symbolization of Lind as a blonde may have also tapped into the newfound subversive connotations of blondness that developed broadly in mid nineteenth-century America and Britain. Importantly, these connections revolved around dualisms and paradoxes that speak to the contrasts Dickinson crafts between feminized ethereality and transgression in her representations of whiteness. The reinscriptions of blondness that occurred in the middle of the nineteenth century also emphasize the degree to which cultural associations of particular colours, styles, and physical attributes are by no means static or universal. Lois Banner notes that the popularization of burlesque and variety shows in the 1850s coincided with "one of the sharpest and most enigmatic style shifts of the century": "For half a century, brown hair had been the favored color. Now light blonde hair became the vogue" (121). In the early nineteenth century, blondness had been out of fashion, in part because studies in physiognomy associated it with blandness and a nondescript, uninteresting personality (Banner 124). The resurgence of blondness was reflected in the popular imagination and through performance, with women actors and dancers taking to peroxide at mid century in increasing numbers. In 1868, the so-called British Blondes (a burlesque troupe from Britain) helped solidify the connection between performance and blondness in America, winning acclaim and attracting controversy during their tour of the United States (121-22). Abigail Heiniger, Lori Landay, and Elisabeth Gitter argue that the transition was reflected in nineteenth-century British and American literature, in works ranging from Harriet Beecher Stowe's Uncle Tom's Cabin (1852) to Bram Stoker's “The Secret of the Growing Gold” (1897). ${ }^{10}$ As

9 Wagenknecht details a relevant and amusing side note to the commercialization of Lind. In Providence, Rhode Island, a chambermaid at the hotel where Lind was staying decided she would do some business on the side and sell strands of Lind's hair to the locals, having convinced them that she had picked them from the "great singer's brush." In truth, the chambermaid was merely selling "hair from her own blonde head" (4).

10 See Landay (62) for a discussion of Uncle Tom's Cabin and Heiniger for a discussion of "The Secret of the Growing Gold.” 
Gitter writes, the "long literary tradition of golden-haired ladies . . . gathered peculiar force in the latter half of the nineteenth century" (936). This tradition consisted of literature, but also visual art, mythology, and other cultural forms which linked blondness to purity, innocence, ethereality, and fragility. However, insofar as positive depictions of blondness represented a transition from the early nineteenth century, this trend was not merely an extension of a pre-existing tradition; rather, it constituted a mid-century shift in style and fashion.

Moreover, the renaissance of blondness did not simply reinforce the old associations of light hair, but also pushed them in a new direction. Banner argues that the eroticized performances of groups like the British Blondes heralded a refreshed openness in America to feminine sensuality on the stage. These performances brought a new edge to the connection between blondness and innocence, showcasing a risqué combination of "purity and voluptuousness" (124). For Gitter, the old ties to innocence and purity remained in place in a number of literary works, but blondness also came to carry a range of antithetical associations, including crass materiality, power, and entrapment. Blonde hair began to function more as a commodity, operating for both virtuous and sinister purposes. Discussing Victorian poets like Lord Tennyson, Robert Browning, and Christina and Dante Rossetti, Gitter writes, "The golden-haired woman they depict, at her most virtuous, may use her hair in the marriage market, saving and trading it for the possibility of wedded bliss. In her more sinister incarnation, she uses it for sexual entrapment and destruction, spending it selfishly for her own pleasure or profit" (946). The alliance between dark hair and sexuality was part of an extended tradition in nineteenth-century British and American literature, with mysterious, forceful, and exotic brunettes like Lady Ligeia in Edgar Allan Poe's "Ligeia" (1838), Cora Munro in James Fenimore Cooper's The Last of the Mobicans (1826), and Eustacia Vye in Thomas Hardy's The Return of the Native (1878) following familiar tropes. The new generation of blonde characters brought their own version of erotic symbolism. The links to purity sharpened sensuousness through contrast, and the associations of gold and wealth strengthened underlying interconnections among sexuality, marriage, and commerce. In many late nine- 
teenth-century literary works, blondness acquires a dialectical volatility, with the traditional connotations now invoking opposite meanings. In works such as Christina Rossetti's "Goblin Market" (1862) (featuring the blonde sisters Laura and Lizzie), purity gives rise to sensuality, innocence to sexual experience, and marriageability to commercial value. The best way for an author to avoid this dialectic, it seems, was to reinforce the earlier associations of blandness, creating eminently good and one-dimensional characters, as Charles Dickens did with Lucie Manette in A Tale of Two Cities (1859).

How and to what extent does Dickinson's poetry take up this cultural and stylistic transition? She deploys the term "blonde" selectively in her poetry, often linking it to sunlight, fire, or gold. She also makes numerous references to amber-as Rebecca Patterson notes, amber is the second most frequently mentioned gemstone in Dickinson's oeuvre, behind pearl (497). The meanings of "blonde" in her poetry are diverse, hinting occasionally at hair colour, as in lines like "Her Forehead is of Amplest Blonde" (Fr735), "Horses of Blonde - and Coach of Silver -" (Fr286), and "The blonde assassin passes on." (Fr1668). ${ }^{11}$ However, in other poems, blondness describes the colour of the sea in sunlight ("You've seen Balloons set - Hav'nt You?"), a flame ("Banish Air from Air -"), and the hue of a chrysalis ("Color Caste - Denomination -"). This article focuses on "The Moon was but a Chin of Gold" and "You've seen Balloons set - Hav'nt You?" to explore interconnections among blondness, ideals of feminine ethereality, and bodily performance.

In the context of these interconnections, the unifying thread between "The Moon was but a Chin of Gold" and "You've seen Balloons set - Hav'nt You?" involves a series of literary elements that speak to dualisms and contradictions which developed within mainstream constructions of blondness in mid nineteenth-century America.

11 The last line comes from "Apparently with no surprise," a poem Dickinson wrote in 1884. Patrick Keane comes closest to offering an interpretation of blondness in Dickinson's poetry in his study of this work. Keane notes that it is surprising that the assassin in the poem is blonde, since the etymological origins of the word invoke Arabic culture. He further argues that the incongruity is meant to emphasize that the pale assassin is, like the flower it destroys, "luminously beautifulpure, prismatic, pristine, glistening” (134). Given the ubiquitous connections between flowers and femininity in Dickinson's poetry, it seems likely that the assassin is intended to be masculine, so the familiar connotations of blondness-including purity and fragility-become ironic in this context. It should be noted, however, that this conflict between the traditional symbolic meanings of blondness and oppositional meanings also emerges in earlier poems. 
These constructions play into select ideals of whiteness, with both poems presenting scenes and imagery evocative of idealized feminine figures that stand above the material world. Motifs of ascension and elevation work in tandem with images of blonde surfaces, golden light, and perfection. Yet these motifs also feed into portrayals of bodily performance. In "The Moon was but a Chin of Gold," the appearance of a full moon in the night sky conjures up images of performance through the slow unveiling of a woman's face, which hangs in the sky as an emblem of celestial perfection. At the same time, this implicit performance also develops aspects of a burlesque show through impressions of the moon's "body." Nonetheless, the abrupt conclusion of the poem, which hints at a sudden death, cuts off the potentially sensual and risque side of the performance. The representation of bodily performance is more explicit in "You've seen Balloons set - Hav'nt You?" as a balloon is personifying a woman who performs on a stage (likely by dancing) for an audience. The performer apparently attempts to use her body in order to transcend physicality and access some form of divine elevation, only to gasp for breath, trip, stumble, and crash to her death. In both of these poems, the motifs of blondness and gold frame aspects of feminized beauty that intersect with traditional associations of blonde hair, such as purity, fragility, and angelic ascension. Then again, they also frame women's performances in relation to displays of the body. However, such displays do not unfold through renditions of sensual or erotic exhibitionism. Rather, they appear through impressions and fragments that introduce themes of death and cessation. Taken together, the poems suggest that ideals of feminine ethereality may be showcased through physical markers (such as blondness and whiteness), but they also imply that physical appearance and bodily performance do not lead to presentations of a simple or cohesive version of a feminine figure as an angelic being that rises above the material world. Rather, insofar as this figure emerges through bodily performance, it does so in piecemeal fragments that ultimately dissolve into moments of diffusion, collapse, and mortality.

The first poem, "The Moon was but a Chin of Gold," presents traditional associations of blondness in relation to staged performance. The poem could be taken as a simple reverie on nature, which 
is how Robin Peel reads it (262-63). It also could be framed as a veneration of feminine beauty, which is how I approach it. From this perspective, the poem offers familiar thematic concerns in literary treatments of feminine beauty, including depictions of ephemerality ("The Moon was but a Chin of Gold/A night or two ago -"; "Her Eye unto the Summer Dew/The likest I have known -") and images of a face that is at once beautiful, remote, and inscrutable ("Her Cheek - a Beryl hewn -"; "Her Lips of Amber never part -"; "And what a privilege to be/But the remotest star -"). The general portrait is one of ideal albeit fleeting beauty suspended above the world. That "Her Forehead is of Amplest Blonde -" extends the imagery of gold while also invoking the resurgence of blondness as a fashionable marker of beauty. The revelation of this blonde head and fair face unfolds as a slow performance. The "Chin of Gold" in the opening line sets up the unveiling that follows: "And now she turns Her perfect Face/Opon [sic] the World below -." This "perfect Face" may reveal a new phase in the construction of beauty - a model of femininity that is at once original and yet traditional.

With regard to blondness, the most noteworthy aspect of the poem is the motif that develops through the "chin of gold," the forehead of "amplest blonde," and the "lips of amber." The colours are similar, but they serve different functions in the poem. If we read the moon as the face of a woman, the chin of gold constitutes the first stage in a slow performance of revelation. The chin is merely a part of the face and its implicit high value (marked through the term "gold") is grounded mainly on potentiality - that is, on the sense of expectation that is only fulfilled when the "perfect Face" appears in subsequent nights. The forehead of "amplest blonde" suggests an abundance and fullness that is perhaps lacking with the mere sliver of the chin. The "lips of amber," meanwhile, point towards another phase in the unveiling of the face. Once the face is revealed in its perfect completeness, it is ready to cast an extraordinary smile "Upon her friend." However, the smile never occurs, as this part of the performance is held in abeyance. On the whole, the imagery of gold, blonde, and amber speaks simultaneously to movement and consistency. The colour of the face does not change substantially as it appears, but the subtle shifts between gold, blonde, and amber empha- 
size that the presentation of the face is a continuous and incomplete process.

How does this portrayal of the moon intersect with transformations in representations of blondness in mid nineteenth-century America and Britain? The "ample" blonde forehead may refer to skin colour, blonde bangs, or perhaps some form of dress, such as a bonnet (which is mentioned in the final stanza). The femininity of the moon and the references to blondness, gold, and amber call to mind associative interconnections between purity, fairness, and light-coloured clothing, hair, and skin. As discussed, the mainstream valorization of Jenny Lind as a performer turned in part on her ability to access a social trend in which whiteness, blondness, and fairness were coded visually to reinforce ideals of feminine virtue. These associations surface through the depiction of the moon as a woman's golden face, but part of what is striking about this representation is the impression of distance and remoteness that persists throughout the poem. In fact, the full revelation of the face only accentuates its continued removal from the viewer (that is, the reader). In the fourth stanza, the speaker states that it would be a privilege for the reader to take on the role of the "remotest star" because then the moon "might pass/Beside your twinkling door." The only way to approach closer to this elevated and seemingly celestial object (or persona) is to become a similar object oneself. If we read the unveiling of the moon as a feminized performance, then it appears to be a slow exhibition of a celestial face, but insofar as ideals of feminine purity are implied in the golden and blonde colouring, they are allied more with inaccessibility than with virtue.

Then again, the final stanza does point toward some of the voluptuousness and sensuality of stage performance, disrupting the ethereal luminosity of the face. This stanza diverges from the rest of the poem by widening the frame to describe attire: "Her Bonnet is the Firmament -/The Universe - Her shoe -/The Stars - the Trinkets at Her Belt -." There is some disjunction in these metaphors. The component parts of attire are basic and unadorned, jarring against the impressions of grandiosity and vastness created by the firmament, universe, and stars. Also, the reference to trinkets deflates the opulence of the gold and silver in the preceding stanzas. The bonnet, 
meanwhile, is an image of containment when set against the "ample" blondness mentioned in the second stanza. One could argue that the discordance only emphasizes the splendour of the face. In other words, the visage is naturally so gorgeous that it is capable of making plain clothes seem like the trappings of universal beauty. On the other hand, the presentation of these clothing and trinkets extends the sense of distance and remoteness that are established in the previous stanzas. The stars, firmament, and universe function as images of expansiveness and universality, but they also provide a sense of shapelessness. If the appearance of the moon emblematizes the disclosure of a feminine performer, then the body of this performer is dispersed across the night sky, to the point that it seems to be simultaneously everywhere and nowhere. The "body" of the performer remains as inaccessible as the face, albeit in a different way. Although the face is distant, it is described in intimate detail. Conversely, the body is only hinted at through descriptions of clothing.

Thus, there might be an element of concealment and obfuscation in the representation of a feminine body, which reaches a subtle level of piquancy in the final line: "Her Dimities - of Blue -." Wardrop asserts that this line provides a "homespun effect, after the plenitude and much-ness of the preceding three lines" ("Body's Body" 44). However, the final line seems to build upon the previous ones. After presenting banal and "safe" pieces of attire, the speaker brings in dimities - skimpy cotton fabrics used in the nineteenth century for bustles, gowns, and undergarments, and often worn in erotic stage performances. Moreover, that they are blue instead of blonde or white is noteworthy, since brighter clothing stands at odds with the symbolic valences of lightness that were allied with feminine purity and virtue in the mid nineteenth century (in the case of Lind, for example). ${ }^{12}$ Nevertheless, these close-fitting garments also fail to reveal the shape of the body. Instead, they mark a possible transition

12 As Mitchell discusses, whereas light-coloured clothing belonged to a series of mid nineteenthcentury American visual markers that melded purity, respectability, and whiteness, brighter-coloured clothing was associated by the same token with ostentatiousness and vulgarity. Mitchell locates a new vogue in the symbolic value of white or light-coloured clothing in the $1850 \mathrm{~s}$ and 60 s, stating that this was a period in which the "middle and upper-middle classes of Northern European descent in America began to reaffirm their identity in opposition to aristocratic excess, vulgar money and other, lower, cultural and ethnic groups" (77-78). 
from night to day, with the "blue" perhaps referring to both the colour of the dimities and the sky at daybreak. Set against a blue sky, the moon would lose its golden colour, becoming white. The suggested transformation might indicate a reversion to a form of purity or blankness, but it could also intimate that the perfect face with its golden hue transforms into a skull, before fading away altogether as the day progresses. From this standpoint, the trajectory of the poem moves from a description of the face to an abortive perception of the body, which comes to a halt with the feminine figure dying and then vanishing.

From a historical perspective, the poem invokes dichotomous associations of blondness and lightness in the mid nineteenth century: feminine ethereality and voluptuous performance. The golden moon may symbolize a new phase in a classic version of beauty, but when the speaker begins describing clothing, the performance begins to shift from the face to the body. This transition builds upon the hints of performance and exhibition that are established in the opening stanza. First, the face gradually comes into view, progressing from a mere golden chin to a full and perfect countenance, and then the clothing starts to appear. The movement towards skimpier clothing (and perhaps undergarments) is symptomatic of a transition towards revealing more of the body, but the poem ends abruptly before this movement is completed. Does the "World below" perhaps expect (or want) the performance to slide into a burlesque or risqué display of the feminine body? It is difficult to answer this question conclusively, given that the performative exhibition is itself implicit, appearing through imagery and suggestion. The poem does, however, create a multivalent setting for the emergence of a feminized face that is coded through the interrelated colours of gold, blonde, and amber. In the context of Dickinson's productively ambivalent treatments of whiteness and feminine purity, the poem offers another way of thinking about tensions between ethereality and bodily performance. The golden and blonde face of the moon plays into traditional ideals of so-called angelic purity, but at the same time, the silence of her performance draws attention to the purely visible. This silence creates some dignity and even grandeur, but the speaker's close description of the face and enumeration of the clothing and accoutrements also 
suggests a desire to see as much of this figure as possible. From this perspective, the shifts between gold, blonde, and amber are based on an intimate scrutiny that only becomes more intense as more of the feminine performer is revealed. The poem never takes up the possible ramifications of a burlesque show, but this might be because the performance ends prematurely with the sudden shift towards dawn.

"You've seen Balloons set - Hav'nt You?" (Fr730), another poem written in 1863, develops a different and arguably more complex portrait of the conflicts between feminized ethereality and bodily performance. The poem is a heavily metaphorical depiction of a balloon rising and falling. The question in the opening line proves to be a bit misleading since it implies that the balloon descends slowly, like either the moon or the sun, when in fact it gets ripped open by a tree and falls into the sea. Lesley Wheeler notes that this "tragic balloon" bears a resemblance to the "fallen women populating nineteenthcentury literature, who ambitiously soar and then fatally stumble" (134). Suzanne Juhasz and Cristanne Miller develop an analogous reading, arguing that the description of the balloon as a "Gilded Creature" (Fr730) may refer to a "painted woman," which could imply a prostitute, actor, or "any woman whose livelihood depends on reputation or public respect" (121). Jessee argues that the balloon represents a woman performer (probably a ballerina) who collapses as she tries to live up to audience expectations (16). I agree that the balloon may represent a woman's performance in front of an audience, invoking public entertainers in general, and perhaps Jenny Lind in particular. However, the interrelated constellations of colour that include blondness, gilt, and whiteness bring out a series of internal conflicts and tensions in the poem, complicating the relationship between the public ascent and subsequent crash.

The opening line of the poem implicates the reader as an observer of the lofty ascent: "You've seen Balloons set - Hav'nt You?" The question might be genuine or rhetorical, depending on the tone. There could also be a touch of condescension in the inquiry-a sense that the reader should have seen this sight. The hint of superciliousness continues in the next lines, with the speaker comparing the balloons to swans that have "discarded You,/For Duties Diamond -." At the same time, the poem veers away from the opening question about 
the descent to a description of an ascent, becoming a picture of a complete process. From the start, the reader is put in the position of an audience member. She is someone watching from below as a higher being takes to the air, only to fall into the sea. The assumption that the reader has previously witnessed this rise and fall suggests that it is a familiar sight, perhaps indicating a performance that is typical if not banal. At the same time, this assumption also serves as the introduction to an intricate description of the event. For the speaker of the poem, it is still worth describing the process of ascent and collapse, even if the reader has already been privy to it. It might be the case that the speaker reiterates a common version of this event, but it is also possible she is providing a new version. If we take up the second possibility, the opening line of "You've seen Balloons set - Hav'nt You?" carries with it an implicit follow up statement: "But you have not really seen them set, so I will show you how it happens."

In the second stanza, the speaker blurs the distinction between the balloons and the swans, expanding the latter into a conceit: "Their Liquid Feet go softly out/Opon [sic] a Sea of Blonde -." In the literal sense, the sea is blonde because it is shimmering in the sunlight, but the lines also create a fluid continuity between the balloons, sun, swans, and sea. That the swans have "Liquid Feet" suggests a lack of separation between their bodies and the sea. There is also a subtle distinction between the swans and balloons: whereas the balloons presumably are floating in the air, the swans "spurn the Air, as 'twere too mean/For Creatures so renowned -." At first glance, this line seems to mean that the swans are too proud to take flight, as though a tangible ascent is unnecessary given their figurative elevation above others. Yet their scorn for the air takes on a sinister dimension in the next stanza, when they "struggle - some - for Breath -." This connection re-establishes the continuity between the balloons and swans by bringing a new angle to one of the initial significations of the metaphor, the elevated superiority of the balloons. In abstract terms, said superiority is based on the rejection of something (symbolized here as air) that surrounds the balloons/swans and is in fact necessary for their survival. The balloons need to be filled with air in order to float and the swans need to breathe air in order to live. Taking this point into account, the "Sea of Blonde" acquires a more ominous meaning. 
The sunlight lends a golden hue to both the water and air, framing the movement of the balloons and swans while contributing to an impression of elevated superiority, but this superiority is based on what appears to be a false rejection of their surroundings.

The image of the blonde sea works in concert with the "Gilded Creature" mentioned in the fourth stanza and the whiteness of the swans, creating a motif that reflects some of the dualisms in Dickinson's treatment of both colour and feminine performance. As mentioned, the "sea of blonde" may refer literally to a body of water bathed in sunlight, but it could also refer symbolically to a large quantity of a specific thing (as in the phrase "a sea of faces"). Might the "sea of blonde" invoke a group of people, such as the blondehaired performers who appeared in America in increasing numbers during the latter half of the nineteenth century? The image seems more abstract than that. Insofar as it is symbolic, it could denote a mass of associative ideas linked to blondness, such as feminine purity, angelic innocence, and ethereality. The swan, an image of both beauty and whiteness, strengthens these associations. On the other hand, the "Gilded Creature" seems to bring out oppositional meanings. "Gilded" implies a cheap coating of gold, carrying associations of empty ostentatiousness and wealth, qualities that stand against the traditional values of blondness and light-coloured clothing that Jenny Lind personified in mid nineteenth-century performance. If we read the sea of blonde as a trope connected to these traditional values, the balloon appears to be at once an extension of them and yet also a deviation from them. As a "Gilded Creature," the balloon rises above the sea of blonde, buoyed into the golden light, but it also constitutes a false reflection of the sea, as though its separation only accentuates its garish exterior.

The third stanza introduces a crowd, strengthening the impression that the balloons and swans are participants in a staged performance:

Their Ribbons just beyond the eye They struggle - some - for Breath And yet the Crowd applaud, below They would not encore - Death - 
The ribbons extend the continuity between the swans and balloons, referring to decorative ribbons that dangle from balloons and also the ribbons of black near a swan's eyes. The second connection brings a dash of foreboding to the scene. This morbid sign is carried forward when the balloons and swans "struggle - some - for Breath -." This line marks a shift in the poem, with the speaker now emphasizing the link between the balloons, the swans, and women performing on a stage. The small struggle for breath is like a concession to physical needs, an indication that the performers are not separate from their surroundings, after all. This transition is completed with the introduction of the crowd in the next line. Jessee states that the crowd either misunderstands the performance or really does want to see some bloodshed (17), but it is important to note how the initial reaction of the crowd is framed: "And yet the Crowd applaud, below -" (my emphasis). This line could mean that the crowd claps even though the performers are dying, but it could also mean that the crowd actually appreciates their surrender to physical needs. In the latter reading, the next line is not, as Jessee states, a disbelieving question (surely the crowd would not encore death-or would they?) but a description of the events unfolding. "They would not encore," meaning, even though the crowd applauds, the performers do not give an encore. The isolated word (“- Death -") therefore functions as a blunt explanation for this failure. So too, this word also binds together mortality and the failure of an encore, emphasizing that death is the one event that will involve no curtain call or aftermath. This interlinked sequence introduces the events of the final two stanzas.

The focus of the poem narrows further in the fourth stanza. The multiple performers are reduced to a single "Gilded Creature" and the language becomes more direct in its allusions to theatrical and bodily performance:

The Gilded Creature strains - and spins -

Trips frantic in a Tree -

Tears open her imperial Veins -

And tumbles in the Sea - 
On the figurative level, the stanza presents an image of an exhausted dancer gasping for breath as she tries to jump and leap, before slamming into the stage in a bloody heap. But even though the invocation of a woman performer is fairly overt here, the speaker also brings the balloons back to the forefront of the poem. The stanza is a portrayal of the performer's collapse and a description of a balloon being torn open by a tree and falling into the sea. Once an image of self-containment and superiority, the balloon is now swept by the wind into a tree, destroyed by the very thing it simultaneously disdained and used to elevate itself. The performer's situation might be analogous, but it seems likelier that it forms a contrast, a point evinced by the distinction between the puncturing of the balloon (releasing air) and the tearing open of the woman's veins (releasing blood). The performer is not destroyed by the air, but collapses because of a lack of it.

The final stanza places more focus on the crowd and the surrounding social context, which includes not only the audience observing the performance but also the group of clerks that apparently orchestrated it. The clerks attempt to nullify the figurative and metaphoric value of the balloon:

The Crowd - retire with an Oath -

The Dust in Streets - go down -

And Clerks in Counting Rooms

Observe - "'Twas only a Balloon” -

These lines describe the official reception of the balloon's fall, inviting a return to the question of the speaker's motives in detailing it. As mentioned, one explanation of these motives is that the speaker wants to provide her own version of this collapse, even if the reader has already witnessed something like it before. Is the speaker therefore attempting to provoke the reader into a reconsideration of how she understands this event? If so, the speaker could be levelling a critique at the clerks' dismissive comment that "'Twas only a Balloon." The heavily metaphoric description of the fall appears to be directed towards eliciting sympathy for the crash of a "Gilded Creature." In this context, the poem as a whole lays stress on reading the fall of the balloon as the elevation and then tragic degradation of 
an individual performer, likely a dancer. This performer does access several traditional ideals allied with blondness and lightness, including fragility (represented by the balloons), purity, and beauty (represented by the swans), but she also personifies an angelic ascent above bodily needs - a rejection of basic elements (including air) and an attempt to capture the celestial associations of the golden light that suffuses the scene. However, the paradox is that the performer must use her body to transcend the purely physical. She must "spin" and "strain" to elevate herself, and ultimately the need for physical activity leads to her crash.

The second half of the poem (lines 10-20) showcases how the conflict between the ethereal and the physical unfolds on the stage. The more the performer tries to fly through the air like a divine being, the more her efforts become apparent. However, either her struggle has no impact on the crowd or they enjoy it as part of the show. Furthermore, as the performer comes closer to a breakdown, the original object, the balloon, re-enters the poem, anticipating the moment when a literal balloon eclipses the performance in the final stanza. The "Clerks in Counting Rooms" bring the poem back to its first line: "You've seen Balloons set - Hav'nt You?" Well, "'Twas only a Balloon." This boomerang arc serves to bracket the poem, eliding the tropological construction of the balloon that develops throughout it. It is as though the clerks attempt to eliminate the feminine performer from the poem. Yet the irony is that the clerks' place within the poem depends on the balloon representing a feminine performer. After all, it is far likelier that an audience would pay to watch a woman perform than to see a balloon drift over the sea. Thus, the clerks' apparent attempt to reduce the balloon to a simple inanimate object with no symbolic value amounts to an act of self-effacement.

As a depiction of feminine performance, the poem spotlights the dualisms that unspool through portrayals of an angelic ascent above the masses and the role the body may play in bringing about this ascension. At the same time, the poem also suggests that the paradoxical attempt to use the body to transcend physicality only emphasizes the inescapable needs of the body. With regard to the wider motifs of blondness and whiteness in Dickinson's literature, the poem deploys a blonde sea as an image that feeds into impressions of celes- 
tial elevation and removal. The paramount image of whiteness in the poem, the swan, signifies another form of elevation that spurns physical necessity. However, the "Gilded Creature" calls to mind a false state of elevation as well as a return of physical needs that proves to be destructive to the performer. Taken together, the motif creates a scene in which an ethereal and feminine persona embodies some of the traditional ideals of blondness and whiteness. The poem suggests that such ideals can be marked on the body through appearance or even adorned through clothing, but it also suggests that trying to inhabit these ideals through bodily performance generates a vicious cycle in which the only way truly to transcend physicality is through death.

Reading "The Moon was but a Chin of Gold" and "You've seen Balloons set - Hav'nt You?" in relation to motifs of blondness brings out a series of conflicts, tensions, and paradoxes that turn on tacit depictions of feminine performance. In both poems, the performance appears through impressions of an object that is suspended above the world. Also, in both works, this elevation works in conjunction with alternating images of blondness, gold, amber, and whiteness, contributing to scenes of regal superiority, dignity, and femininity. At the same time, each poem hints at fragmented appearances of a body, which feed into moments of death and terminus. The reader is situated in the position of an audience member-someone from the "world below" or the "crowd." From this perspective, the reader is able to watch a performance that takes on the form of a celestial ascension. However, in each work, the performance ultimately deviates from a display of ethereality into a piecemeal and abortive presentation of a feminine body. Thus, in the context of cultural reconstructions of blondness in the mid nineteenth century, one of the most significant elements in these poems is their seeming resistance to representing a coexistence between the dual connotations of blondness - that is, connotations of purity, ethereality, and innocence, and those of risqué sensuousness and eroticism. Do the poems therefore suggest that such a coexistence is impossible? Perhaps, but they also emphasize the general failure of the performances to reveal anything but the purely visual. Insofar as the metaphoric performances are filtered through depictions of the moon and a balloon, they serve to 
emphasize the silence of the performer. In both poems, the performer remains distant, voiceless, and ephemeral, appearing briefly before fading out or crashing to her death. The poems showcase the way visual signs (including colour) may capture variegated aspects of feminine performance while revealing nothing about the performer herself. From this standpoint, it is not the case that the poems lament the intrusion of physicality or eroticism into an idealized display of feminine elevation. Rather, they direct attention to the ways that different stages of a performance may simultaneously reveal diverse tropes of femininity while failing to bring any specificity to the identity of the performer. 


\section{ÚTDRÁTTUR}

\section{Gylltar verur pjást og deyja: \\ Ljóst hár og yfirjarðneskir eiginleikar kvenna \\ í ljóðum Emily Dickinson}

Í ljóðum sínum fæst Emily Dickinson við pær mótsagnir og tvíhyggju sem fólust í almennum hugmyndum um ljóst hár á nítjándu öld. Ljóst hár var samkvæmt hefð tengt hugmyndum um kvenlegt sakleysi, fullkomnun og yfirjarðneska eiginleika en um miðja nítjándu öld öðlaðist pessi háralitur nýjar og mótsagnakenndar merkingar í bandarískri dægurmenningu par sem hann tengdist grófum efnislegum veruleika og líkamstjáningu. Í greininni er fjallað um pessar breytingar út frá tveimur af ljódum Dickinson, „The Moon was but a Chin of Gold“ og „You’ve seen Balloons set - Hav'nt You?", par sem dregin er upp mynd af ljósu hári og kvenlegri túlkun. Sett eru fram rök fyrir pví að Dickinson ýki kraftmikið samspil mótsagnakenndra hugmynda um ljóst hár og fangi um leið hugmyndir um himneskan hreinleika og nautnalega túlkun sem vinna saman og hvor gegn annarri.

Lykilorð: Emily Dickinson, leikur/túlkun, ljóst hár, kvenleiki, dægurmenning 


\section{Works Cited}

The following abbreviation is used to refer to the writings of Emily Dickinson:

Fr The Poems of Emily Dickinson. Ed. R. W. Franklin. 3 vols. Harvard UP, 1998. Citation by poem number.

L The Letters of Emily Dickinson. Eds. Thomas H. Johnson and Theodora Ward. 3 vols. Harvard UP, 1958. Citation by letter number.

Banner, Lois. American Beauty. Alfred A. Knopf, 1983.

Bollobás, Enikő. "Troping the Unthought: Catachresis in Emily Dickinson's Poetry." Emily Dickinson Journal, vol. 21, no. 1, 2012, pp. 25-56.

Boziwick, George. "Emily Dickinson's Music Book: A Performative Exploration.” Emily Dickinson Journal, vol. 25, no. 1, 2016, pp. 83-105.

Caci, Ursula. "Interchangeability and Mutuality: The Relativity of Power in Dickinson's Gendered Relationships.” Emily Dickinson Journal, vol. 23, no. 2, 2014, pp. 69-91.

Cooper, James Fenimore. The Last of the Mobicans. Harvard UP, 2011.

Cooper, Wendy. Hair, Sex, Society, and Symbolism. Stein and Day, 1971.

Dickens, Charles. A Tale of Two Cities. Modern Library, 1996.

Gelbart, Nina. "The Blonding of Charlotte Corday." Eighteenth-Century Studies, vol. 38, no. 1, 2004, pp. 201-21.

Gilbert, Sandra and Susan Gubar. The Madwoman in the Attic: The Woman Writer and the Nineteenth-Century Literary Imagination. Yale UP, 1979.

Gitter, Elisabeth. "The Power of Women's Hair in the Victorian Imagination." PMLA, vol. 99, no. 5, 1984, pp. 936-54.

Hardy, Thomas. The Return of the Native. Norton, 2006.

Heiniger, Abigail. "Undead Blond Hair in the Victorian Imagination: The Hungarian Roots of Bram Stoker's 'The Secret of the Growing Gold.” AHEA, vol. 4, 2011, n. pag, web. 3 Feb. 2019.

Jessee, Jessica. "'an orator of feather unto an audience of fuzz': Performance as Subject and Setting in Emily Dickinson's Poems." Emily Dickinson Journal, vol. 23, no. 2, 2014, pp. 1-23.

Joncus, Berta. “Ich bin eine Engländerin, zur Freyheit geboren': Blonde and the Enlightened Female in Mozart's Die Entführung aus dem Serail." Opera Quarterly, vol. 26, no. 4, 2010, pp. 552-87.

Juhasz, Suzanne. "Introduction: Feminist Critics Read Emily Dickinson.” Feminist Critics Read Emily Dickinson, edited by Juhasz, Indiana UP, 1983.

Juhasz, Suzanne and Cristanne Miller. "Performances of Gender in Dickinson's Poetry." The Cambridge Companion to Emily Dickinson, edited by Wendy Martin, Cambridge UP, 2002, pp. 107-28.

Keane, Patrick. Emily Dickinson's Approving God: Divine Design and the Problem of Suffering. UP of Missouri, 2008. 
King, Wesley. “The White Symbolic of Emily Dickinson.” Emily Dickinson Journal, vol. 18, no. 1, 2009, pp. 44-68.

Landay, Lori. Madcaps, Screwballs, and Con Women: The Female Trickster in American Culture. UP of Pennsylvania, 1998.

Miller, Cristanne. Reading in Time: Emily Dickinson in the Nineteenth Century. UP of Massachusetts, 2012.

Mitchell, Domnhall. "Northern Lights: Class, Color, Culture, and Emily Dickinson." Emily Dickinson Journal, vol. 9, no. 2, 2000, pp. 75-83.

Morgan, Victoria. Emily Dickinson and Hymn Culture: Tradition and Experience. Ashgate, 2010.

Mossberg, Barbara. "Emily Dickinson's Nursery Rhymes." Feminist Critics Read Emily Dickinson, edited by Suzanne Juhasz, Indiana UP, 1983, pp. 45-66.

Parks, Cecily. "The Swamps of Emily Dickinson.” Emily Dickinson Journal, vol. 22, no. 1, 2013, pp. 1-29.

Pascoe, Judith. “'The House Encore Me So': Emily Dickinson and Jenny Lind.” Emily Dickinson Journal, vol. 1, no. 1, 1992, pp. 1-18.

Patterson, Rebecca. "Emily Dickinson's Jewel Imagery." American Literature, vol. 42, no. 4, 1971, pp. 495-520.

Peel, Robin. Emily Dickinson and the Hill of Science. Fairleigh Dickinson UP, 2010.

Pitman, Joanna. On Blondes. Bloomsbury, 2003.

Pollak, Vivian. "Dickinson and the Poetics of Whiteness." Emily Dickinson Journal, vol. 9, no. 2 2000, pp. 84-95.

Reynolds, David. "Emily Dickinson and Popular Culture." The Cambridge Companion to Emily Dickinson, edited by Wendy Martin, Cambridge UP, 2002, pp. 167-90.

Rossetti, Christina. "Goblin Market." The Complete Poems, edited by R. W. Crump, Louisiana State UP, 1979, pp. 11-25.

St. Armand, Barton Levi. Emily Dickinson and Her Culture: The Soul's Society. Cambridge UP, 1984.

Stoker, Bram. "The Secret of the Growing Gold." Dracula's Guest and Other Weird Stories. Penguin, 2006, pp. 50-63.

Stoneley, Peter. “I - Pay - in Satin Cash -’: Commerce, Gender, and Display in Emily Dickinson's Poetry.” American Literature, vol. 72, no. 3, 2000, pp. 575-94.

Stowe, Harriet Beecher. Uncle Tom's Cabin. Oxford UP, 2002.

Wagenknecht, Edward. Seven Daughters of the Theatre. UP of Oklahoma, 1964.

Walker, Cheryl. "Dickinson in Context: Nineteenth-Century American Women Poets." A Historical Guide to Emily Dickinson, edited by Vivian Pollak, Oxford UP, 2004, pp. 175-200.

Wardrop, Daneen. “The Body's Body: Dickinson's Fashions and Amplitude.” Emily Dickinson Journal, vol. 14, no. 2, 2005, pp. 34-47.

---. Emily Dickinson and the Labor of Clothing. UP of New Hampshire, 2009.

Wheeler, Lesley. The Poetics of Enclosure: American Women Poets from Dickinson to Dove. UP of Tennessee, 2002. 